\title{
BMJ Global Health Transparency in IHR emergency committee decision making: the case for reform
}

\author{
Mark Eccleston-Turner, ${ }^{1}$ Adam Kamradt-Scott ${ }^{\circledR}$
}

To cite: Eccleston-Turner M, Kamradt-Scott A. Transparency in IHR emergency committee decision making: the case for reform. BMJ Glob Health 2019;4:e001618. doi:10.1136/ bmjgh-2019-001618

Received 4 April 2019 Accepted 6 April 2019

\section{Check for updates}

(c) Author(s) (or their employer(s)) 2019. Re-use permitted under CC BY-NC. No commercial re-use. See rights and permissions. Published by BMJ.

${ }^{1}$ School of Law, Keele University, Keele, Staffordshire, UK ${ }^{2}$ Centre for International Security Studies, University of Sydney - Camperdown and Darlington Campus, Sydney, New South Wales, Australia

\section{Correspondence to} Dr Mark Eccleston-Turner; m.r.eccleston-turner@keele. ac.uk

\section{INTRODUCTION}

The current outbreak of Ebola virus disease (EVD) in the Democratic Republic of the Congo (DRC) is the second largest in history. Only the 2014-2016 West African EVD outbreak has exceed it. The current outbreak is characterised by community mistrust, opposition to vaccination and treatment, and ongoing conflict in the region. The combination of these factors has meant that, despite the best efforts of the WHO, the DRC government and aid agencies in the region, cases and deaths continue to grow on a weekly basis. The severity of the outbreak, as well as the potential for cross-border spread has led to a number of calls for the WHO to declare the outbreak a Public Health Emergency of International Concern (PHEIC) under the International Health Regulations 2005 (IHR 2005). It is hoped that such a declaration would instigate the delivery of badly needed resources to contain the outbreak. Despite this, no PHEIC declaration has been forthcoming.

\section{EBOLA, THE DRC AND THE EMERGENCY COMMITTEE (EC) PROCESS}

Under the IHR 2005, the WHO Director-General is empowered to declare a PHEIC. In making this determination though, the Director-General is required to take into account a number of factors including the risk to human health, the risk of international spread and the advice of a technical expert committeethe IHR EC. ${ }^{1}$ Each EC is convened by the Director-General with its membership drawn from a list of technical experts that have been preapproved and recommended by governments. Importantly, however, ECs are not standing committees; they are assembled on ad hoc basis with each committee's membership purposively selected according to aetiological agent involved (if known) and/or nature of the event. Once convened, the EC reviews all available data on the event and then advises the Director-General whether the conditions for a PHEIC have been met. If the EC ascertains the conditions have been met, the committee is required to provide recommendations on what actions the Director-General and Member States should take to address the crisis.

The requirement for the Director-General to take advice from an independent technical expert group in determining a PHEIC was a new addition to the revised IHR 2005 framework. Its creation reflected Member States' discomfort over the level of autonomy exhibited by the WHO Secretariat in declaring a global health emergency during the 2003 SARS outbreak. Crucially, however, the role of the IHR EC is to conduct a technical assessment of a public health crisis using a predetermined algorithm and legal criteria and, on the basis of that technical assessment, recommend whether a PHEIC should be declared or not.

In the context of the current EVD outbreak in the DRC, the IHR EC has been convened on two ocassions - in October 2018, ${ }^{2}$ and again in April 2019. ${ }^{3}$ The IHR EC has advised against declaring a PHEIC, despite the criteria for doing so appearing to be met on both ocassions. By the Committee's own acknowledgement the on-the-ground situation has substantially worsened - a situation corroborated by several other sources. On 8 March 2019 for instance, Médecins Sans Frontières warned of a 'toxic' environment and 'a climate of deepening community mistrust'. ${ }^{4}$ Within days, an attack on an Ebola clinic forced its temporary closure after a policeman was killed and a healthcare worker was wounded, but similar attacks targeting healthcare clinics had been underway for several months. ${ }^{5}$ By late March, an in-depth study confirmed that widespread community 
distrust was hampering efforts to contain the outbreak, with many refusing vaccination, hiding symptoms and refusing treatment, even as the number of confirmed cases exceeded one thousand. ${ }^{6}$

Given the criteria for declaring a PHEIC appeared to have been met at the October 2018 IHR EC meeting, questions have arisen as to why no declaration was made then. It is even more perplexing that the IHR EC's recommendation remains unchanged at the conlusion of its April 2019 meeting. This confusion has not been made easier by the fact the rationale provided at the October 2018 meeting for why a PHEIC was unjustified was not especially clear, only that 'a PHEIC should not be declared at this time'. ${ }^{7}$ This language of this statement was markedly different from the language of past ECs that recommended a PHEIC should not be declared. Indeed, in the 13 previous instances of an EC recommending that a PHEIC ought not be declared, every previous committee stated, 'the conditions for a PHEIC are not currently met' or the event 'does not constitute a PHEIC'. The October 2018 meeting is the only time an EC has deviated from this standard terminology. While not conclusive, it is suggestive the IHR EC's advice was not based on PHEIC criteria alone but that other factors may also have been considered. Likewise, at the April 2019 meeting, the IHR EC advised against a PHEIC being declared because, in the committee's view, 'there is no added benefit to declaring a PHEIC at this stage', and they further noted there has yet to be 'international spread' beyond the borders of the DRC. ${ }^{3}$ This is despite the fact that they acknowledged the 'very high risk of regional spread', the ongoing and complex nature of the current outbreak, the 'recent increase in transmission in specific areas' and the 'critical need to strengthen current efforts in both preparedness and response'. Indeed, the notion of 'added benefit' is not part of the PHEIC criteria laid down in the International Health Regulations, and as such is superfluous to the treaty's established legal requirements. These two statements naturally raise questions about how an EC arrives at its recommendations and the transparency of that deliberation process.

\section{THE IMPORTANCE OF TRANSPARENCY}

Concerns about the transparency of IHR EC processes and decision making are not new. Until relatively recently, even the names of IHR EC members were not publicly known or shared. While this policy was changed in 2011, ${ }^{8}$ on the basis that 'The Organization [...] recognized that it requires greater transparency to maintain the trust of the public' (WHO, p 119), ${ }^{8}$ that is currently the limit of transparency in IHR EC deliberations. Given the crucial role the EC plays in determining whether a PHEIC ought to be declared, coupled with the central importance of the PHEIC declaration for responding to health crises (including pandemics), we argue any concerns regarding the transparency of IHR EC processes undermines the decisions reached, the legitimacy of those decisions and their processes and, by association, the IHR 2005 and the treaty's custodian, the WHO.

Transparency is widely considered to be central to good governance. Transparency ensures accountability, ${ }^{9}$ and both validates and defends the legitimacy of the processes followed and decisions made and the actors involved in the decision-making process. ${ }^{10}$ As the International Law Association in its Study on the Accountability of International Organizations observed, 'transparency in...the decision-making process and the implementation of... decisions' as well as 'access to information open to all potentially concerned and/or affected by the decisions at stake' is constitutive of the 'principle of good governance'. ${ }^{11}$ It is for these very reasons that various international organisations, including the United Nations (UN), have repeatedly sought to embrace increased transparency in decision making.

\section{ALTERNATIVES TO THE CURRENT MODEL}

The UN Security Council (UNSG) has the primary responsibility for international peace and security in international law. Despite the highly sensitive nature of the Security Council deliberations, the Council normally meets and makes decisions in public along with a live webcast, verbatim records of statements made during the deliberation process, and evidence taken are kept and published on the UNSC website. Indeed, even some private meetings that the Council holds are officially recorded, although with no verbatim record and fewer details logged, as per the Rules of Procedure of the Council. ${ }^{12}$ While concerns the UNSC lacks transparency in some of its work have been raised, particularly around the use of 'Arria-Formula' meetings, the Security Council model does contain important lessons for future reform of the IHR EC process. Moving towards a greater transparency of the IHR ECs, including live webcast of the meetings and publishing a verbatim record of the discussion in all official UN working languages would, in our view, increase the transparency and legitimacy of the work of the Committee, its decisions and, by implication, the legitimacy of the International Health Regulations.

Having said this, we acknowledge there are times when security-sensitive information warrants increased discretion. Both DRC EC meetings heard evidence from the Office of the Deputy Special Representative of the Secretary-General on the work of the United Nations Organization Stabilization Mission in the Demoratic Republic ofthe Congo (MONUSCO), the UN Peacekeeping mission in the DRC, including its logistics and security activities in the DRC, provides one example where elements of an IHR EC's deliberations may require censorship. This process can be managed, however, while still promoting transparency around IHR EC deliberations more broadly. For instance, any evidence or discussion that alludes to information that could place healthcare workers in danger, such as the location and movement of healthcare workers or the security services in a region, 
could be managed whereby the live feed is temporarily halted and the information redacted from the verbatim record. This will allow frank and open discussion of health concerns in a complex conflict zone, such as the DRC, while ensuring the overall decision-making process remains transparent and legitimate.

\section{CONCLUSION}

Until there is increased transparency around EC Deliberations, questions about irrelevant considerations, undue influence and political interference will continue to arise. These concerns can be easily addressed given existing information technology capabilities, and interventions such as live streaming IHR EC discussions and verbatim records will provide the entire international community with critical insights into how a public health crisis is unfolding and what the WHO is doing to contain it. This is a simple change to existing WHO practices that is long overdue, and in so doing, it will alleviate ongoing concerns about how EC members arrive at their decisions and strengthen the legitimacy of the WHO, which is charged with protecting the international community against the spread of disease.

Contributors Both authors contributed jointly to the production of this manuscript. The authors have not declared a specific grant for this research from any funding agency in the public, commercial or not-for-profit sectors.

Competing interests None declared.

Patient consent for publication Not required.

Provenance and peer review Commissioned; internally peer reviewed.

Data availability statement № additional data are available.

Open access This is an open access article distributed in accordance with the Creative Commons Attribution Non Commercial (CC BY-NC 4.0) license, which permits others to distribute, remix, adapt, build upon this work non-commercially, and license their derivative works on different terms, provided the original work is properly cited, appropriate credit is given, any changes made indicated, and the use is non-commercial. See: http://creativecommons.org/licenses/by-nc/4.0/.

\section{REFERENCES}

1. International Health Regulations. Article 12 2005;4.

2. WHO. Statement on the October 2018 meeting of the IHR emergency Committee on the Ebola virus disease outbreak in the Democratic Republic of the Congo. World Health organization, 17 October 2018. Available: https://www.who.int/news-room/detail/ 17-10-2018-statement-on-the-meeting-of-the-ihr-emergencycommittee-on-the-ebola-outbreak-in-drc [Accessed 14 Jan 2019].

3. World Health Organisation. Statement on the Meeting of the international health regulations (2005) emergency Committee for Ebola virus disease in the Democratic Republic of the Congo on 12th April, 2019. Available: https://www.who.int/news-room/detail/ 12-04-2019-statement-on-the-meeting-of-the-international-healthregulations-(2005)-emergency-committee-for-ebola-virus-diseasein-the-democratic-republic-of-the-congo-on-12th-april-2019 [Accessed 16 Apr 2019].

4. Child D. 'Toxic' atmosphere undermining DRC Ebola outbreak response: MSF. Al Jazeera, 2019. Available: https://www.aljazeera. $\mathrm{com} /$ news/2019/03/toxic-atmosphere-undermining-drc-ebolaoutbreak-response-msf-190307142358603.html [Accessed 4 Apr 2019].

5. Anonymous. 'It breaks my heart': WHO chief decries raid on DRC Ebola centre. Al Jazeera, 2019. Available: https://www.aljazeera. com/news/2019/03/breaks-heart-chief-decries-raid-drc-ebolacentre-190309193641595.html [Accessed 4 Apr 2019].

6. Anonymous. Community mistrust worsening DR Congo Ebola outbreak: study. al Jazeera, 2019. Available: https://www.aljazeera. com/news/2019/03/community-mistrust-worsening-dr-congo-ebolaoutbreak-study-190328062938247.html [Accessed 4 Apr 2019].

7. WHO. 17 October 2018.

8. WHO. Implementation of the International Health Regulations (2005) - Report of the Review Committee on the Functioning of the International Health Regulations (2005) in relation to Pandemic (H1N1) 2009 (2011) A64/10, 2019. Available: http://apps.who.int/gb/ ebwha/pdf_files/WHA64/A64_10-en.pdf

9. Grigorescu A. Transparency of Intergovernmental organizations: the roles of member States, International Bureaucracies and nongovernmental organizations. International Studies Quarterly 2007:51:625-48.

10. Hovell D. The Deliberative Deficit: Transparency, Access to Information and UN Sanctions. In: Farrall JM, Rubenstein K, eds. Sanctions, accountability and governance in a globalized world. 99. Cambridge: Cambridge University Press, 2009.

11. International Law Association. Report of the Seventy-First conference. 172. London: International Law Association, 2004.

12. United Nations Security Council. Provisional ROP in un doc S/96/ Rev.7. Geneva: United Nations, 1982. 